\title{
PERBANDINGAN MODEL CHEN DAN MODEL LEE PADA METODE FUZZY TIME SERIES UNTUK PREDIKSI HARGA EMAS
}

\author{
Lestari Handayani ${ }^{1}$, Darni Anggriani ${ }^{2}$ \\ ${ }^{1,2}$ Informatics Department, Faculty of Sciences and Technology \\ State Islamic University of Sultan Syarif Kasim Riau, Pekanbaru - Indonesia \\ ${ }^{1}$ lestari.handayani@uin-suska.ac . id ${ }^{1}$ \\ ${ }^{2}$ darnianggriani@yahoo.co.id ${ }^{2}$
}

Abstrak: Emas merupakan suatu investasi penting dalam perekonomian yang harganya lebih cenderung menaik dan bukan menurun sehingga banyak dari para investor atau manajer investasi yang berupaya memprediksi harga emas untuk hari besok. Sistem prediksi menggunakan fuzzy time series berguna untuk menangkap pola data yang telah lalu yang kemudian digunakan untuk menghasilkan informasi di waktu yang akan datang. Dalam fuzzy time series terdapat berbagai model diantaranya model Chen dan Lee, untuk mengetahui model mana yang menghasilkan tingkat keakuratan yang tepat dengan menghitung tingkat error menggunakan AFER dan MSE. Dalam perhitungan fuzzy time series, panjang interval telah ditentukan diawal proses. Dalam proses ini panjang interval sangat berpengaruh untuk hasil prediksi. Metode untuk penentuan panjang interval yang efektif adalah dengan metode berbasis rata-rata atau average-based fuzzy time series, sehingga pembentukan fuzzy relationship akan tepat dan menghasilkan hasil prediksi yang efektif. Dari hasil pengujian yang dilakukan dengan menggunakan data dari tahun Januari 2007 hingga 29 mei 2012, diketahui bahwa prediksi data menggunakan fuzzy time series dengan penetuan interval berbasis rata-rata memiliki error dengan model Chen AFER sebesar 0,010\% dan MSE 218,577, model Lee rata-rata AFER 0,0013\% dan MSE 212,092. Dari hasil pengujian yang telah dilakukan dapat dibuktikan metode fuzzy time series menggunakan model Lee menghasilkan tingkat error lebih rendah dibanding model Chen.

Kata kunci: Average based fuzzy time series, prediksi emas, model Chen, model Lee

Abstract: Gold is an important investment in the economy which tends to cost more increase decrease so many of the investors or fund managers are predicting the price of gold for the next day. The system uses fuzzy time series prediction is useful for capturing data pattern that has occured which used to generate information at a future. There are various models in the fuzzy time series such as Chen and Lee, for find out which model produces the appropriate level of accuracy by calculating the error level using AFER and MSE. In fuzzy time series calculating the length of interval have been determined at the beginning of the process, in this process lengthy intervals is very influential for prediction result. The more efective method for determining the length of the interval is averagebased fuzzy time series. So the formation of fuzzy relationshipwill correct and produce an effective prediction. From the results of tests performed by using data from January 2006 May 29, 2012, note that the predicted data using fuzzy time series with interval determination based on average have an error level with Chen model result AFER $0,010 \%$ and MSE 218.577 Lee models result AFER 0,0013\% and MSE
212.092. From the results of testing that has been done can be proved that using the method of fuzzy time series Lee models result error level more lower than Chen model.

Key words: Average Based Fuzzy time series, gold prediction, Chen model, Lee model

\section{PENDAHULUAN}

Beberapa tahun terakhir mulai bermunculan bermacam-macam investasi, antara lain tabungan, emas, reksa dana dan lain-lain. Salah satu investasi yang sedang berkembang sekarang adalah investasi emas, sehingga mulai bermunculan lembagalembaga yang mengedarkan emas di Indonesia. Lembaga tersebut antara lain Gerai Dinar (GD), PT. (Aneka Tambang) ANTAM. Tbk dan London Bullion Market Association (LBMA). Harga emas yang cenderung menaik dan membutuhkan sistem yang dapat membantu untuk mengetahui prediksi harga emas diwaktu yang akan datang. 
Salah satu metode untuk memprediksi harga emas yaitu dengan fuzzy time series, penelitian ini telah dilakukan untuk memprediksi kurs rupiah terhadap dollar amerika [1] dimana metode ini dapat menangkap pola dari data yang telah lalu kemudian digunakan untuk memproyeksikan ke masa yang akan datang. Dalam metode fuzzy time series terdapat berbagai model yaitu model Song, Chissom, Chen dan Lee.

Dalam penelitian ini, penulis mencoba membandingkan hasil prediksi harga emas dengan menggunakan model Chen dan model Lee pada metode fuzzy time series, dimana pada proses fuzzy time series panjang interval telah ditentukan diawal proses karena panjang interval sangat berpengaruh dalam hasil prediksi, sehingga pembentukan fuzzy relationship akan tepat. Metode untuk penentuan panjang interval yang efektif adalah dengan metode berbasis rata-rata atau average-based fuzzy time series [9].

\section{LANDASAN TEORI}

Time series (deret waktu) adalah data yang disusun berdasarkan urutan waktu atau data yang dikumpulkan dari waktu ke waktu. Waktu yang digunakan dapat berupa hari, minggu, bulan, tahun dan sebagainya. Data time series sangat berguna bagi pengambil keputusan untuk memperkirakan atau meramalkan kejadian di masa yang akan datang. Karena diyakini pola perubahan data time series beberapa periode masa lampau akan kembali terulang pada masa kini.

Metode fuzzy time series menggunakan model Song dan Chissom diimplementasikan untuk memprediksi jumlah pendaftaran [6], kemudian model Song dan Chissom ini digunakan untuk memprediksi cuaca [7] kurangnya tingkat keakuratan dengan menggunakan model tersebut kemudian disempurkan oleh Chen [7] dan kemudian pada tahun 2009 ditemukanlah model Lee yang dianggap lebih baik dalam hal memprediksi dengan metode fuzzy time series dibanding model Chen dalam hal keakuratan atau evaluation MSE paling kecil [8].

\section{METODOLOGI PENELITIAN}

Langkah pengerjaan penelitian ini tergambar pada Gambar 1. Pada tahap awal dilakukan pengumpulan data secara time series dari harga emas dimana pada penelitian ini digunakan data time series harga emas selama 6 tahun yaitu dari tahun 2007-2012, yang didapatkan dari situs The London Bullion Market Association (LBMA). Selain itu, pada tahap ini juga dilakukan pencarian informasi-informasi mengenai metode prediksi yang akan digunakan yaitu fuzzy time series dan metode average based (Penentuan Interval Berbasis Rata-rata) sebagai metode pembagian interval dalam fuzzy time series. Adapun pendekatan yang penulis lakukan dalam memperoleh informasi-informasi yang dibutuhkan dalam penelitian diantaranya adalah Studi Pustaka (Library Research).

Pada tahap kedua dilakukan analisa data masukan, analisa terhadap metode yang digunakan untuk prediksi data harga emas dan analisa data keluaran. Dimana metode yang digunakan adalah metode fuzzy time series dengan model Chen dan Model Lee [8] dan metode Average Based (Penentuan Interval Berbasis Rata-rata) [9] sebagai metode pembagian interval dalam fuzzy time series. Dimana dalam perhitungannya terdapat tiga proses perhitungan utama yaitu:

1. Proses pembagian interval

2. Proses fuzzy time series

3. Proses perhitungan defuzzifikasi menggunakan model Chen dan model Lee. 
Berikut secara umum seluruh langkah-langkah dari ketiga proses perhitungan utama yang akan digunakan untuk melakukan prediksi terhadap data harga emas:

a. Hitung jumlah selisih (lag) absolut antar data time series dan proses menggunakan metode Average Based.

b. Tentukan semesta pembicaraan $U$ (Universe of Discourse) berdasarkan hasil proses average based dan bagi kedalam beberapa interval yang memiliki panjang interval sama.

c. Tentukan Himpunan Fuzzy Ai.

d. Tentukan fuzzy logical relationship $A i \rightarrow A j$

e. Tentukan Fuzzy Logical Relationship Group (FLRG).

f. Lakukan proses defuzzifikasi dan melakukan perhitungan nilai prediksi.

g. Hitung tingkat error dari prediksi. Untuk menganalisa sistem menggunakan Data Flow Diagram (DFD).

Tahapan ketiga dari penelitian ini yaitu perancangan. Perancangan ini terdiri dari : perancangan database dan perancangan Interface. Selanjutnya di tahapan keempat yaitu implementasi dan pengujian. Implementasi pengembangan aplikasi ini akan dikembangkan menggunakan bahasa pemrograman Borland Delphi 6 dan database Microsoft Access 2003. Sedangkan pada pengujian dilakukan pengujian yang telah dibangun yaitu pengujian blackbox untuk pengujian tingkah laku sistem yang telah dirancang dan untuk menghitung tingkat keakuratan hasil prediksi atau evaluation dengan dengan menggunakan Average Forecasting Error Rate (AFER) dan Mean Square Error (MSE) untuk melihat tingkat keerorran terendah dari Model Chen dan Model Lee.

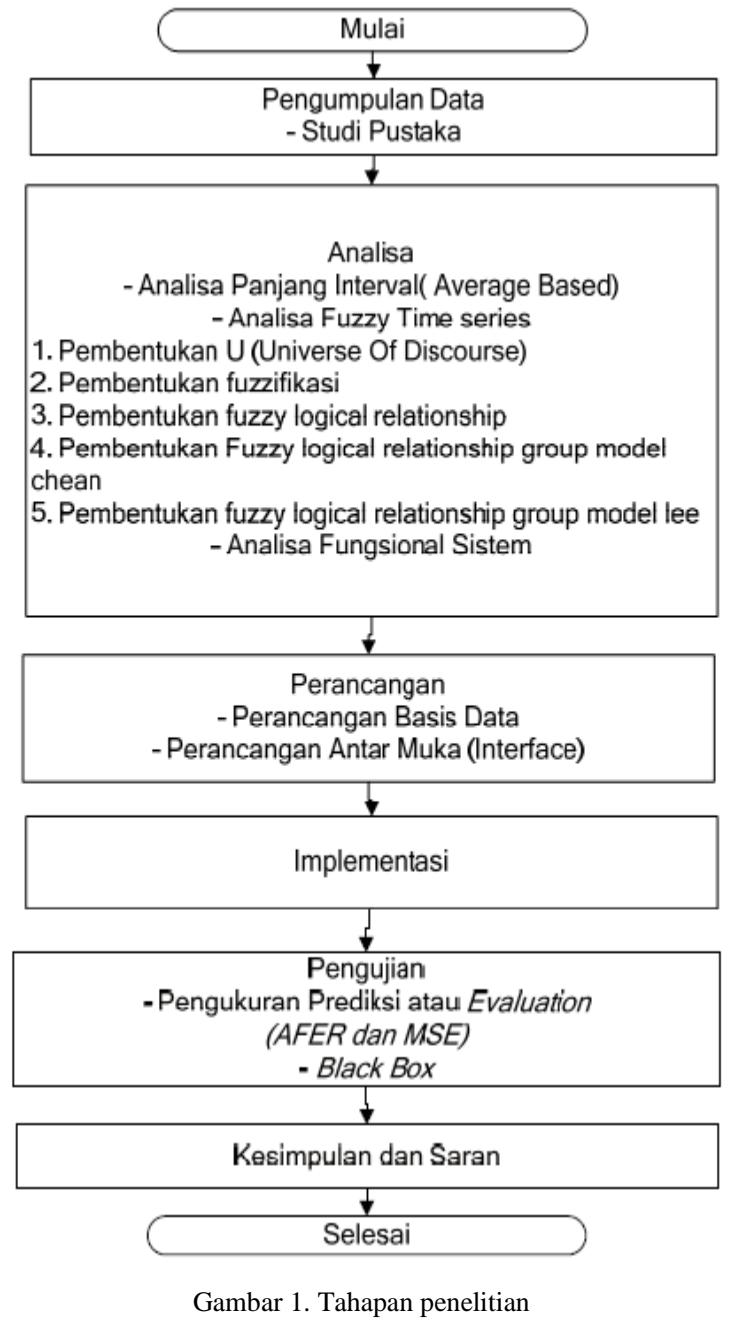

\section{IV.HASIL DAN PEMBAHASAN}

Implementasi untuk prediksi harga emas ini berupa sebuah sistem prediksi yang menerapkan model dari metode Fuzzy Time series (FTS) dan menggunakan metode Average Based (Penentuan Interval Berbasis Rata-rata) sebagai metode untuk pembagian interval. Data masukan untuk melakukan prediksi adalah data time series dari harga emas, yang selanjutnya akan diproses dengan perhitungan menggunakan model dari metode FTS. Untuk lebih jelasnya Gambaran umum sistem dapat dilihat pada Gambar 2. 


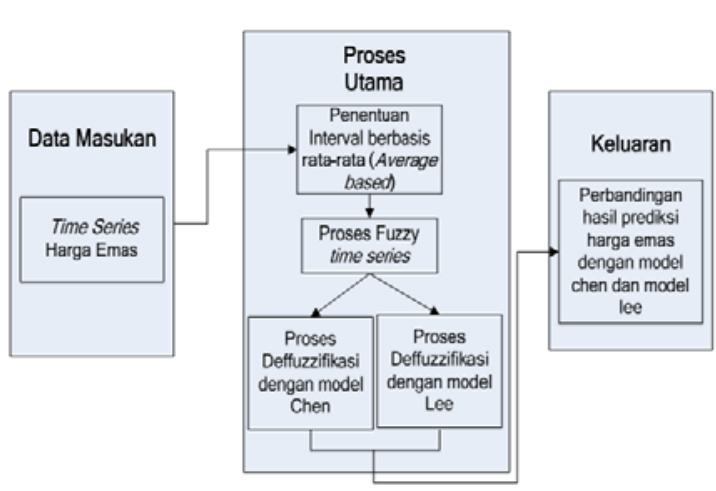

Gambar 2. Gambaran Umum Sistem

\section{Analisa Data Masukan}

Data masukan yang akan digunakan pada sistem prediksi adalah data time series harian dari harga emas dan selanjutnya akan dilakukan perhitungan prediksi menggunakan metode FTS untuk menghasilkan prediksi harga emas hari berikutnya. Adapun data time series harga emas yang akan digunakan untuk prediksi diperoleh dari situs The london Bullion Market Association (LBMA) selama 6 tahun.

Adapun alasan digunakannya data harga emas perusahaan dengan jumlah data time series selama 6 tahun adalah untuk melihat apakah ada perbedaan persentase error dari AFER dan MSE atau tingkat ketepatan prediksi dari hasil prediksi yang didapatkan, sehingga dapat memberikan kesimpulan akhir apakah semakin banyak jumlah data time series yang digunakan akan memberikan hasil prediksi lebih akurat atau sebaliknya. Pada Tabel 1 adalah data harga emas pada tahun 2012 yang akan digunakan sebagai percobaan perhitungan.
Tabel 1. Data Harga Emas Tahun 2012

\begin{tabular}{|c|c|c|c|}
\hline DATE & $\begin{array}{c}\text { Harga/US } \\
D\left(D_{i}\right)\end{array}$ & DATE & $\begin{array}{c}\text { Harga/US } \\
D\left(D_{i}\right)\end{array}$ \\
\hline 03-Jan-12 & 1580.00 & 30-Jan-12 & 1720.50 \\
\hline 04-Jan-12 & 1603.00 & 31-Jan-12 & 1738.00 \\
\hline $05-J a n-12$ & 1614.50 & 01-Feb-12 & 1744.00 \\
\hline 06-Jan-12 & 1621.00 & 02-Feb-12 & 1747.50 \\
\hline 09-Jan-12 & 1618.00 & 03-Feb-12 & 1759.50 \\
\hline $10-\operatorname{Jan}-12$ & 1627.00 & $06-$ Feb- 12 & 1717.00 \\
\hline 11-Jan-12 & 1641.00 & 07-Feb-12 & 1720.00 \\
\hline $12-\operatorname{Jan}-12$ & 1652.50 & 08 -Feb-12 & 1743.00 \\
\hline $13-\operatorname{Jan}-12$ & 1642.00 & 09-Feb-12 & 1733.00 \\
\hline 16-Jan-12 & 1643.50 & 10-Feb-12 & 1715.50 \\
\hline 17-Jan- 12 & 1662.00 & 13-Feb-12 & 1727.00 \\
\hline 18-Jan-12 & 1657.00 & 14-Feb-12 & 1721.00 \\
\hline 19-Jan-12 & 1664.00 & $15-\mathrm{Feb}-12$ & 1725.50 \\
\hline 20-Jan-12 & 1646.00 & 16-Feb-12 & 1716.00 \\
\hline 23-Jan- 12 & 1675.00 & 17-Feb-12 & 1732.00 \\
\hline 24-Jan-12 & 1669.00 & 20-Feb-12 & 1729.50 \\
\hline $25-\operatorname{Jan}-12$ & 1659.00 & 21-Feb-12 & 1737.00 \\
\hline 26-Jan- 12 & 1713.00 & $22-\mathrm{Feb}-12$ & 1754.75 \\
\hline 27-Jan-12 & 1722.00 & $23-F e b-12$ & 1776.50 \\
\hline
\end{tabular}

\begin{tabular}{|c|c|}
\hline DATE & $\begin{array}{c}\text { Harga/USD } \\
\left(\mathrm{D}_{\mathrm{i}}\right)\end{array}$ \\
\hline 24-Feb-12 & 1778.50 \\
\hline 27-Feb-12 & 1765.00 \\
\hline 28-Feb-12 & 1774.75 \\
\hline 29-Feb-12 & 1790.00 \\
\hline $01-$ Mar-12 & 1721.00 \\
\hline $02-$ Mar-12 & 1714.50 \\
\hline $05-$ Mar-12 & 1698.00 \\
\hline $06-$ Mar-12 & 1685.50 \\
\hline $07-$ Mar-12 & 1682.50 \\
\hline $08-$ Mar-12 & 1701.50 \\
\hline $09-$ Mar-12 & 1699.50 \\
\hline 12-Mar-12 & 1705.25 \\
\hline 13-Mar-12 & 1694.75 \\
\hline 14-Mar-12 & 1662.00 \\
\hline 15-Mar-12 & 1646.75 \\
\hline $16-$ Mar-12 & 1649.00 \\
\hline 19-Mar-12 & 1654.00 \\
\hline 20-Mar-12 & \\
\hline
\end{tabular}

Analisa Metode Fuzzy Time Series (FTS) untuk Prediksi Emas

Pada dasarnya metode FTS memiliki langkah awal penting yang harus diperhatikan karena memiliki pengaruh terhadap keakuratan hasil prediksi yaitu dalam penentuan jumlah interval. Berdasarkan penelitian Huarng dan Yu [10] bahwa perbedaan panjang interval akan sangat mempengaruhi hasil prediksi dan tingkat error prediksi serta penentuan panjang interval tidak boleh terlalu besar dan tidak boleh terlalu kecil, karena jika panjang interval terlalu besar maka tidak akan terjadi fluktuasi dalam proses perhitungan metode FTS.

Pada penelitian ini menggunakan metode Fuzzy Time series dan menggunakan metode Average Based (Penentuan Interval Berbasis Rta-rata) sebagai metode pembagian interval. Berdasarkan penelitian-penelitian yang ada terdapat beberapa cara untuk menentukan jumlah interval dan pada penelitian ini menggunakan metode Average Based (Penentuan Interval Berbasis Rata-rata) yang memberikan hasil prediksi lebih akurat dibandingkan metode pembagian interval lainnya [9]. Adapun Gambaran khusus porses prediksi menggunakan metode Fuzzy Time series dengan 
penentuan interval berbasis rata-rata (Average Based) dapat dilihat pada Gambar 3.

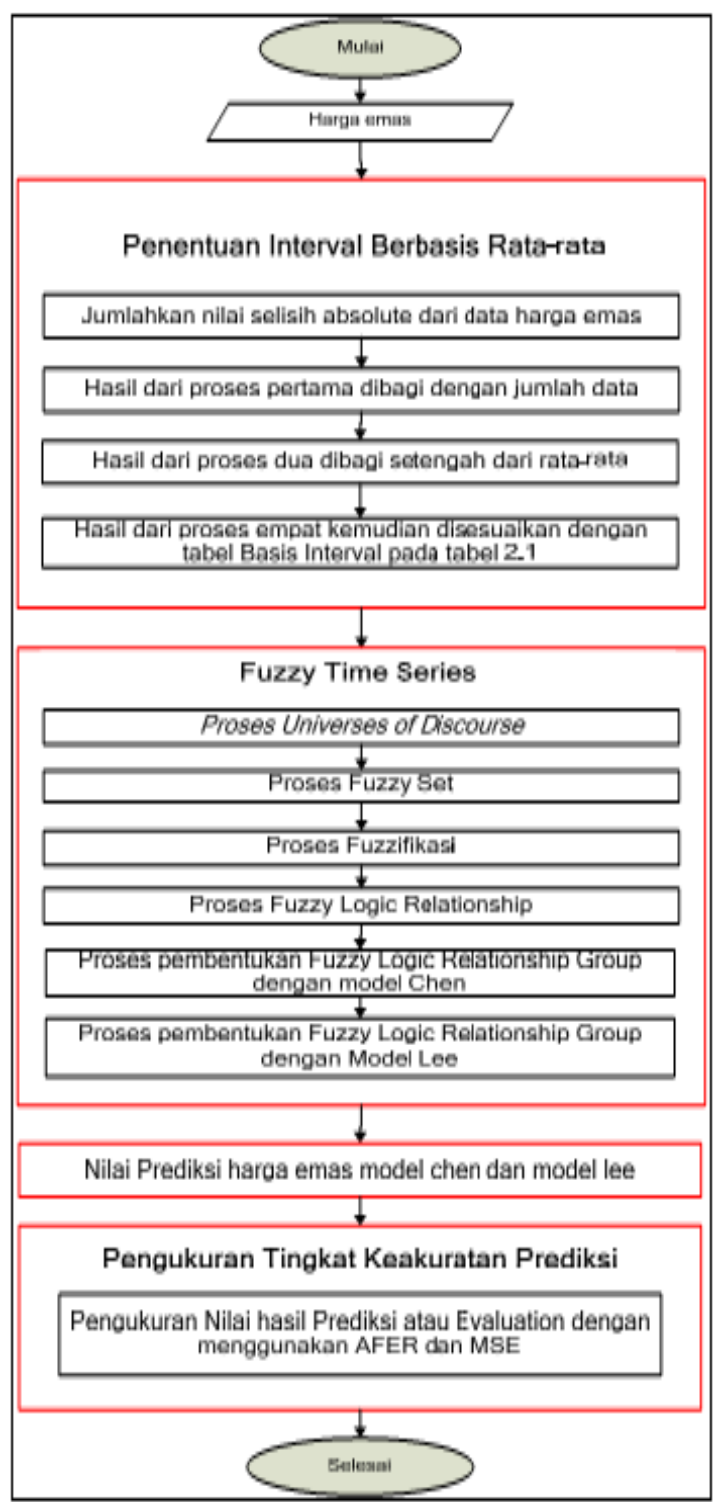

Gambar 3. Gambaran khusus proses prediksi menggunakan metode Fuzzy Time series dengan penentuan interval berbasis rata-rata

Proses penentuan interval berbasis rata-rata

Dalam penerapan menggunakan penentuan interval dengan average based terdapat 4 tahapan dalam proses tersebut. Berikut adalah proses penentuan interval.

1. Hitungan selisih (lag) absolut pada tiap data, dengan rumus (1), hasil proses dapat dilihat pada Tabel 2

$$
\sum_{i=1}^{\mathrm{n}-1}\left|\left(\mathrm{D}_{\mathrm{i}+1}\right)-\left(\mathrm{D}_{\mathrm{i}}\right)\right|
$$

Data harga emas pada tahun 2012 mulai tanggal 3 di bulan januari sampai 19 maret yang akan digunakan sebagai percobaan perhitungan. Total data untuk perhitungan analisa ini berjumlah 55 data emas.

Tabel 2. Perhitungan Data lag atau selisih absolut untuk

\begin{tabular}{|c|c|c|c|}
\hline No & DATE & $\begin{array}{l}\text { Harga/USD } \\
\text { (Di) }\end{array}$ & $\begin{array}{c}\text { Selisih (Lag) } \\
\left|\mathrm{D}_{(\mathrm{i}+1)}-\mathrm{D}_{(\mathrm{i})}\right|\end{array}$ \\
\hline 1 & 03-Jan-12 & 1580 & $\left|\mathrm{D}_{2}-\mathrm{D}_{1}\right|=23$ \\
\hline 2 & 04-Jan-12 & 1603 & $\left|\mathrm{D}_{3}-\mathrm{D}_{2}\right|=11,5$ \\
\hline 3 & 05-Jan-12 & 1614,5 & $\left|\mathrm{D}_{4}-\mathrm{D}_{3}\right|=6,5$ \\
\hline 4 & 06-Jan-12 & 1621 & $\left|\mathrm{D}_{5}-\mathrm{D}_{4}\right|=3$ \\
\hline$\cdots$ & $\ldots .$. & $\ldots . .$. & $\cdots \cdots$ \\
\hline 54 & 16-Mar-12 & 1649 & $\left|\mathrm{D}_{55}-\mathrm{D}_{54}\right|=5$ \\
\hline 55 & 19-Mar-12 & 1654 & - \\
\hline \multicolumn{4}{|c|}{$\sum=721$} \\
\hline
\end{tabular}
Penentuan Interval

2. Kalkulasikan semua nilai selisih (lag) absolut kemudian dibagi dengan jumlah data, didapatkan 721/54 = 13,35

3. Untuk menentukan basis interval hasil proses 2 kemudian dibagi 2 sehingga menjadi 13,35/2 = 6,67, yang nilainya dibulatkan menjadi 7, sehingga basis 1 dalam jangkauan 1.1-10.

4. Didapatkan panjang interval 7.

\section{Fuzzy Time series}

Berikut adalah tahapan proses fuzzy time series:

1. Proses pertama dari fuzzy time series adalah pembentukan universe of discourse U. Dari data harga emas yang terdapat pada Tabel 2, kita mencari nilai minimal dan maksimal, diperoleh $(\operatorname{Dmin}=1580$, Dmax $=1790)$. Proses pembentukan U (Universe of Discourse) diperoleh sebagai berikut: $(1790-1580) / 7=30$, maka didapatkan panjang intervalnya adalah 
30, kemudian data dibagi menjadi 30 yaitu U1, U2,U3.....U30

$\mathrm{U}_{1}=[1580,1587], \mathrm{U}_{2}=[1587,1594], \quad \mathrm{U}_{3}=[1594,1601], \mathrm{U}_{4}=[1601,1608]$, $\mathrm{U}_{5}=[1608,1615], \mathrm{U}_{6}=[1615,1622], \mathrm{U}_{7}=[1622,1629], \mathrm{U}_{8}=[1629,1636]$, $\mathrm{U}_{9}=[1636,1643], \mathrm{U}_{10}=[1643,1650], \mathrm{U}_{11}=[1650,1657], \mathrm{U}_{12}=[1657,1664]$, $\mathrm{U}_{13}=[1664,1671], \mathrm{U}_{14}=[1671,1678], \mathrm{U}_{15}=[1678,1685], \mathrm{U}_{16}=[1685,1692]$ $\mathrm{U}_{17}=[1692,1699], \mathrm{U}_{18}=[1699,1706], \mathrm{U}_{19}=[1706,1713], \mathrm{U}_{20}=[1713,1720]$ $\mathrm{U}_{21}=[1720,1727], \mathrm{U}_{22}=[1727,1734], \mathrm{U}_{23}=[1734,1741], \mathrm{U}_{24}=[1741,1748]$ $\mathrm{U}_{25}=[1748,1755], \mathrm{U}_{26}=[1755,1762], \mathrm{U}_{27}=[1762,1769], \mathrm{U}_{28}=[1769,1776]$, $\mathrm{U}_{29}=[1776,1783], \mathrm{U}_{30}=[1783,1790]$,

2. Tentukan tiap-tiap himpunan fuzzy Ai sebanyak interval yang telah dibagi sebelumnya yang dapat dilihat pada rumus 2. Untuk menyederhanakan, maka nilai keanggotaan dari himpunan fuzzy Ai_berada diantara 0, 0.5, 1 dimana $1=i=n_{-}, n$ adalah jumlah interval yang telah dibagi sebelumnya, berikut adalah bentuk matriks dari pembentukan himpunan fuzzy, yang dapat dilihat pada Tabel 3.

$a_{\mathrm{ij}}= \begin{cases}1 & \text { If }=j=i \\ 0.5 & \text { If } j=i-1 \text { atau } i+1 \\ 0 & \text { yang lainnya }\end{cases}$

Tabel 3. Matriks himpunan fuzzy

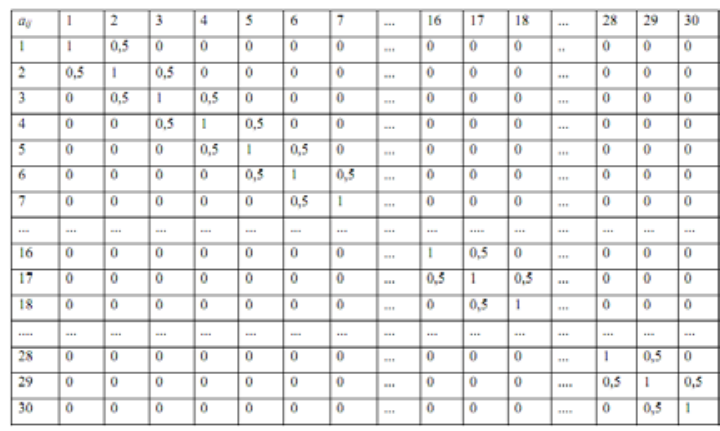

Dari Tabel 3 tersebut menghasilkan himpunan fuzzy berdasarkan rumus 3 .

$$
\begin{gathered}
A_{1}=a_{11} / U_{1}+a_{12} / U_{2}+\ldots+a_{1 \mathrm{n}} / U_{\mathrm{n}} \\
A_{2}=a_{21} /{ }_{U 1}+a_{22} /{ }_{U 2}+\ldots+a_{2 \mathrm{n}} / U_{\mathrm{n}} \\
\ldots \\
A_{\mathrm{k}}=a_{\mathrm{k} 1} /{ }_{U 1}+a_{\mathrm{k} 2} /{ }_{U 2}+\ldots+a_{\mathrm{kn}} / U \mathrm{n}
\end{gathered}
$$

Dengan hasil sebagai berikut:

$\mathrm{A} 1=1 / u 1+0,5 / u 2+0 / u 3+0 / u 4+0 / u 5+0 / u 6+$ $0 / u 7+0 / u 8+0 / u 9+0 / u 10+0 / u 11+0 / u 12+$

$$
\begin{aligned}
& 0 / u 13+0 / u 14+0 / u 15+0 / u 16+0 / u 17+0 / u 18+ \\
& 0 / u 19+0 / u 20+0 / u 21+0 / u 22+0 / u 23+0 / u 24+ \\
& 0 / u 25+0 / u 26+0 / u 27+0 / u 28+0 / u 29+0 / u 30 \\
& \mathrm{~A} 2=0,5 / u 1+1 / u 2+0,5 / u 3+0 / u 4+0 / u 5+0 / u 6+ \\
& 0 / u 7+0 / u 8+0 / u 9+0 / u 10+0 / u 11+0 / u 12+ \\
& 0 / u 13+0 / u 14+0 / u 15+0 / u 16+0 / u 17+0 / u 18+ \\
& 0 / u 19+0 / u 20+0 / u 21+0 / u 22+0 / u 23+0 / u 24+ \\
& 0 / u 25+0 / u 26+0 / u 27+0 / u 28+0 / u 29+0 / u 30
\end{aligned}
$$

.....

$\mathrm{A} 30=0 / u 1+0 / u 2+0 / u 3+0 / u 4+0 / u 5+0 / u 6+$

$0 / u 7+0 / u 8+0 / u 9+0 / u 10+0 / u 11+0 / u 12+$

$0 / u 13+0 / u 14+0 / u 15+0 / u 16+0 / u 17+0 / u 18+$

$0 / u 19+0 / u 20+0 / u 21+0 / u 22+0 / u 23+0 / u 24+$

$0 / u 25+0 / u 26+0 / u 27+0 / u 28+0,5 / u 29+1 / u 30$

3. Tentukan fuzzy logical relationship $A i \rightarrow A j$ berdasarkan nilai $A i$ yang telah ditentukan pada langkah sebelumnya, dimana $A i$ adalah tahun $n$ dan $A j$ tahun $n+1$ pada data time series yang dapat dilihat pada Tabel 4 .

Tabel 4. Penentuan Fuzzy Logical Relationship

\begin{tabular}{|c|c|c|l|}
\hline DATE & USD / Harga & Fuzzifikasi & Relationship \\
\hline 03-Jan-12 & 1580 & $\mathrm{~A} 1$ & - \\
\hline 04-Jan-12 & 1603 & $\mathrm{~A} 4$ & $\mathrm{~A} 1=>\mathrm{A} 4$ \\
\hline 05-Jan-12 & 1614,5 & $\mathrm{~A} 5$ & $\mathrm{~A} 4=>\mathrm{A} 5$ \\
\hline 06-Jan-12 & 1621 & $\mathrm{~A} 6$ & $\mathrm{~A} 5=>\mathrm{A} 6$ \\
\hline$\ldots . .$. & $\ldots \ldots$. & $\ldots \ldots .$. & $\ldots \ldots .$. \\
\hline 16-Mar-12 & 1649 & $\mathrm{~A} 10$ & $\mathrm{~A} 10=>\mathrm{A} 10$ \\
\hline 19-Mar-12 & 1654 & $\mathrm{~A} 11$ & $\mathrm{~A} 10=>\mathrm{A} 11$ \\
\hline
\end{tabular}

4. Dari hasil fuzzy logic relationship masuk dalam proses defuzzifikasi atau fuzzy logical relationship group menggunakan model Chen. Semua Fuzzy logic Relationship dikelompokkan. Misal (Ai): $\mathrm{Ai} \rightarrow \mathrm{Aj}, \mathrm{Ai} \rightarrow \mathrm{Aj} 1$ dan $\mathrm{Ai} \rightarrow \mathrm{Aj}$. Dari 3 fuzzy logic relationship dapat dikelompokkan. Chen akan menghasilkan $\mathrm{Ai} \rightarrow \mathrm{Aj} 2, \mathrm{Ai} \rightarrow \mathrm{Aj}$, yang mana $\mathrm{Ai} \rightarrow \mathrm{Aj} 1, \mathrm{Ai}$ $\rightarrow \mathrm{Aj}$, dianggap sama sehingga diambil hanya satu. Pada Tabel 5 Hasil FLRG menggunakan model Chen : 
Tabel 5. Fuzzy logical relationship group (FLRG) dan Defuzifikasi menggunakan model Chen

\begin{tabular}{|c|c|c|c|}
\hline $\begin{array}{c}\text { Current } \\
\text { state }\end{array}$ & Next state & Perhitungan & $\begin{array}{c}\text { Nilai } \\
\text { Prediksi }\end{array}$ \\
\hline $\mathrm{A} 1 \rightarrow$ & A4 & 1604,5 & 1604,5 \\
\hline $\mathrm{A} 4 \rightarrow$ & A5 & 1611,5 & 1611,5 \\
\hline $\mathrm{A} 5 \rightarrow$ & $\mathrm{A} 6$ & 1618,5 & 1618,5 \\
\hline $\mathrm{A} 6 \rightarrow$ & $\mathrm{A} 6, \mathrm{~A} 7$ & $\cdots \cdots$ & 1622 \\
\hline$\cdots .$. & $\cdots .$. & 1786,5 & $\cdots .$. \\
\hline $\mathrm{A} 28 \rightarrow$ & $\mathrm{A} 30$ & $(1779,5+1765,5) / 2$ & 1786,5 \\
\hline $\mathrm{A} 29 \rightarrow$ & $\mathrm{A} 29, \mathrm{~A} 27$ & 1723,5 & 1772,5 \\
\hline $\mathrm{A} 30 \rightarrow$ & $\mathrm{A} 21$ & & 1723,5 \\
\hline
\end{tabular}

5. Dari hasil fuzzy logic relationship masuk dalam proses defuzzifikasi atau fuzzy logical relationship group menggunakan model Lee. Semua Fuzzy logic relationship dikelompokkan atau fuzzy logic relationship group (FLRG) menjadi kelompok yang saling berhubungan. Misal (Ai): $\mathrm{Ai} \rightarrow \mathrm{Aj} 1, \mathrm{Ai} \rightarrow \mathrm{Aj}_{1}$ dan $\mathrm{Ai} \rightarrow \mathrm{Aj}_{2}$. Dari 3 fuzzy logic relationship dapat dikelompokkan. Lee akan menghasilkan Ai $\rightarrow \mathrm{Aj}_{1}, \mathrm{Ai} \rightarrow \mathrm{Aj}_{1}$ dan $\mathrm{Ai} \rightarrow \mathrm{Aj} 2$, menurut Lee Ai $\rightarrow \mathrm{Aj} 1$, Ai $\rightarrow \mathrm{Aj}_{2}$ dapat mempengaruhi nilai prediksi maka nilai tersebut harus dihitung. Tabel 6 merupakan hasil FLRG menggunakan model Lee.

Tabel 6. Fuzzy Logical Relationship Group (FLRG) menggunakan model Lee

\begin{tabular}{|c|c|c|c|}
\hline $\begin{array}{c}\text { Current } \\
\text { state }\end{array}$ & Next state & Perhitungan & $\begin{array}{c}\text { Nilai } \\
\text { Prediksi }\end{array}$ \\
\hline $\mathrm{A} 1 \rightarrow$ & A4 & 1604,5 & 1604,5 \\
\hline $\mathrm{A} 4 \rightarrow$ & $\mathrm{A} 5$ & 1611,5 & 1611,5 \\
\hline $\mathrm{A} 5 \rightarrow$ & $\mathrm{A} 6$ & 1618,5 & 1618,5 \\
\hline $\mathrm{A} 6 \rightarrow$ & $\mathrm{A} 6, \mathrm{~A} 7$ & $(1 / 2)(1618,5)+(1 / 2)(1625,5)$ & 1622 \\
\hline$\cdots \cdots$ & $\cdots \cdots$ & $\cdots \cdots$ & $\ldots .$. \\
\hline $\mathrm{A} 28 \rightarrow$ & A30 & 1786,5 & 1786,5 \\
\hline $\mathrm{A} 29 \rightarrow$ & A29, A27 & $(1 / 2)(1779,5)+(1 / 2)(1765,5)$ & 1772,5 \\
\hline $\mathrm{A} 30 \rightarrow$ & A21 & 1723,5 & 1723,5 \\
\hline
\end{tabular}

Kemudian data hasil prediksi emas menggunakan model Chen dan Lee dapat diperbandingkan, bisa ditampilkan dalam bentuk tabel atau grafik.

\section{Perancangan Sistem}

Dalam perancangan dilakukan perancangan basis data, yaitu dibangun basis data dengan dengan nama basis data "Harga Emas" dimana terdiri dari 3 Tabel, yaitu Tabel harga emas, Tabel Fuzzy Logic Relationship dan Tabel Hasil. Selanjutnya dirancang tampilan antar muka, diantaranya terlihat pada gambar 4 dan gambar 5 ..

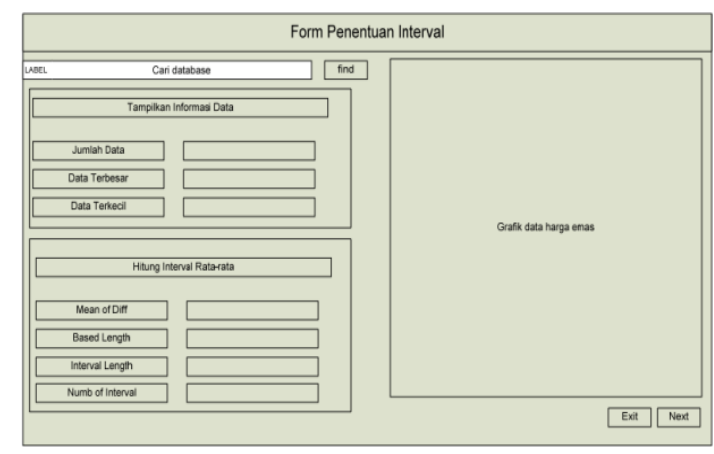

Gambar 4. Interface untuk Form penentuan interval

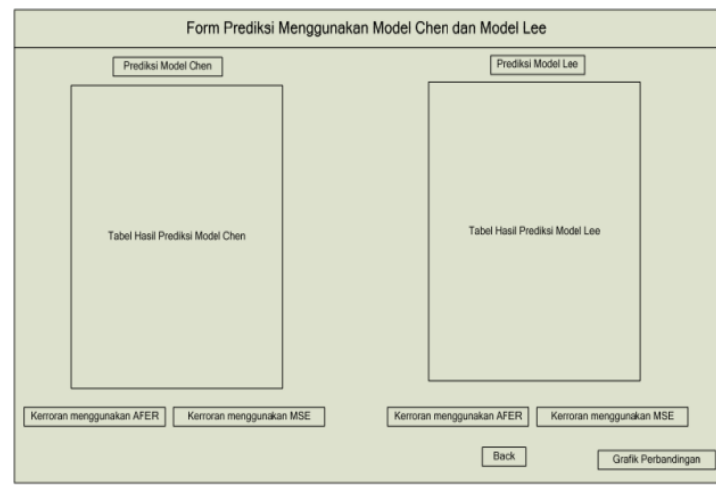

Gambar 5. Interface untuk Form Prediksi Model Chen dan Model Lee

\section{Hasil Implementasi Penentuan Interval}

Implementasi sistem dalam form penentuan interval berbasis rata-rata terlihat pada gambar 6 .

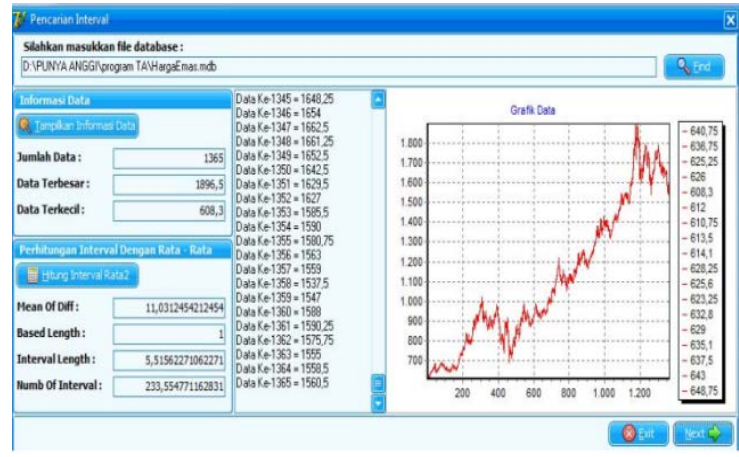

Gambar 6. Tampilan Form Pencarian Interval

Berikut gambar 7 adalah implementasi sistem dalam proses perbandingan hasil prediksi antara 
data sebenarnya, hasil prediksi model Chen dan hasil perdiksi model Lee dalam bentuk grafik.

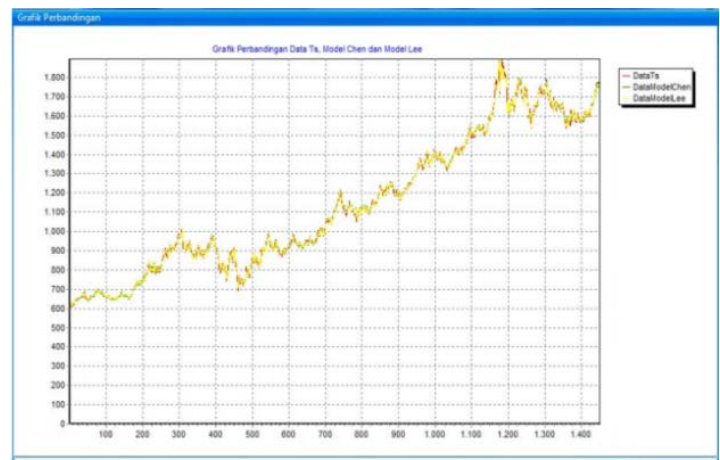

Gambar 7. Tampilan Form Grafik Perbandingan Hasil

\section{Pengujian}

Pengujian sistem pada aspek keakuratan nilai prediksi yaitu dilakukan dengan menguji dan membandingkan hasil nilai prediksi dengan nilai kebenaran harga emas yang sebenarnya. Dari hasil pengukuran tingkat keakuratan data didapatkan hasil perhitungan dengan sistem perbandingan hasil selama percobaan 14 hari berturut turut dari tanggal 01 Oktober 2012 - 17 Oktober 2012 menggunakan data dari tahun 2007 didapatkan hasil percobaan yang terlihat pada tabel 7 .

Tabel 7. Perbandingan hasil prediksi

\begin{tabular}{|l|l|l|l|l|l|l|l|}
\hline TGL & \multicolumn{1}{|c|}{ Data } & $\begin{array}{c}\text { Prediksi } \\
\text { Model } \\
\text { Chen }\end{array}$ & $\begin{array}{c}\text { Prediksi } \\
\text { Model Lee }\end{array}$ & $\begin{array}{c}\text { AFER } \\
\text { Model } \\
\text { Chen }\end{array}$ & $\begin{array}{c}\text { MSE } \\
\text { Model } \\
\text { Chen }\end{array}$ & $\begin{array}{c}\text { AFER } \\
\text { model } \\
\text { Lee }\end{array}$ & $\begin{array}{c}\text { MSE } \\
\text { Model } \\
\text { Lee }\end{array}$ \\
\hline $1 / 10 / 12$ & 1770,50 & 1783,45 & 1777,71 & $0,99 \%$ & 218,4 & $0,94 \%$ & 211,7 \\
\hline $2 / 10 / 12$ & 1778,50 & 1757,78 & 1757,78 & $0,99 \%$ & 218,2 & $0,94 \%$ & 211,8 \\
\hline $3 / 10 / 12$ & 1777,25 & 1785,68 & 1778,28 & $0,99 \%$ & 218,3 & $0,96 \%$ & 211,8 \\
\hline $4 / 10 / 12$ & 1786,50 & 1773,12 & 1768,01 & $0,99 \%$ & 218,1 & $1 \%$ & 211,7 \\
\hline $5 / 10 / 12$ & 1790,00 & 1755,92 & 1755,92 & $0,99 \%$ & 218,1 & $0,94 \%$ & 211,7 \\
\hline $6 / 10 / 12$ & Libur & - & - & - & - & - & - \\
\hline $7 / 10 / 12$ & Libur & - & - & - & - & - & - \\
\hline $8 / 10 / 12$ & 1769,00 & 1802,42 & 1802,42 & $0,99 \%$ & 218,7 & $0,91 \%$ & 212,2 \\
\hline $9 / 10 / 12$ & 1770,75 & 1763,36 & 1763,36 & $0,99 \%$ & 219,2 & $2,09 \%$ & 212,7 \\
\hline $10 / 10 / 12$ & 1763,00 & 1764,48 & 1764,48 & $0,99 \%$ & 219,1 & $3,09 \%$ & 212,6 \\
\hline $11 / 10 / 12$ & 1767,25 & 1766,15 & 1767,35 & $1,98 \%$ & 218,9 & $0,94 \%$ & 212,4 \\
\hline $12 / 10 / 12$ & 1767,00 & 1764,48 & 1764,29 & $1,16 \%$ & 218,8 & $1,18 \%$ & 212,3 \\
\hline $13 / 10 / 12$ & Libur & - & - & - & - & - & - \\
\hline $14 / 10 / 12$ & Libur & - & - & - & - & - & - \\
\hline $15 / 10 / 12$ & 1747,25 & 1764,48 & 1764,29 & $0,99 \%$ & 218,6 & $2,18 \%$ & 212,1 \\
\hline $16 / 10 / 12$ & 1737,50 & 1741,07 & 1741,07 & $0,99 \%$ & 218,6 & $1,48 \%$ & 212,1 \\
\hline $17 / 10 / 12$ & 1747,75 & 1740,11 & 1740,11 & $0,99 \%$ & 218,5 & $1 \%$ & 212,1 \\
\hline
\end{tabular}

Dari hasil pengujian yang telah dilakukan bahwa aplikasi prediksi ini telah dapat memberikan hasil yang diharapkan oleh penulis yakni output harga emas pada keesokan harinya ini sesuai dengan analisa dan perancangan. Dari hasil percobaan didapatkan hasil rata-rata tingkat error atau hasil evaluasi menggunakan Model Chen AFER 0,010\%, MSE 218,577 dan Model Lee AFER 0,0013\%, MSE 212,092.

\section{V.KESIMPULAN}

Setelah melalui tahap analisis dan pengujian pada aplikasi perbandingan hasil prediksi Fuzzy Time series dengan model Chen dan model Lee, maka dapat diambil suatu kesimpulan sebagai berikut:

1. Sistem prediksi harga emas menggunakan fuzzy time series pada model Chen dan model Lee dengan penentuan interval berbasis rata-rata dapat memberikan hasil harga emas untuk keesokan harinya.

2. Prediksi dengan Metode Fuzzy time series antara Model Chen dan Lee yang menghasilkan nilai tingkat error yang rendah adalah menggunakan model Lee dengan nilai keerroran Chen AFER 0,010\%, MSE 218,577 dan Model Lee AFER 0,0013\%, MSE 212,092. Adapun saran sebagai berikut:

1. Diharapkan dapat menampilkan perkembangan harga emas perbulan pada setiap tahunnya.

2. Diharapkan untuk penelitian selanjutnya dapat menggunakan metode Candlestick Chart karena dapat menghasilkan hasil prediksi yang lebih akurat.

\section{REFERENS}

[1] Ahmad Amiruddin Anwary. "Prediksi Kurs Rupiah Terhadap Dollar Amerika Menggunakan Metode Fuzzy Time series”. 2011.

[2] Chen, S. M. "Forecasting enrollments based on fuzzy time series”. Fuzzy Sets and Systems, 81: 311-319. 1996..

[3] Chen, S. M. "Forecasting enrollments based on HighOrder fuzzy time series”. Cybernetics and Systems, 33: 116. 2002. 
[4] Kusumadewi, S., Purnomo,H. Aplikasi Logika Fuzzy untuk Pendukung Keputusan. Graha Ilmu. Yogyakarta. 2004.

[5] M. Syauqi Haris. Implementasi Metode Fuzzy Time series Dengan Penentuan Interval Berbasis Rata-rata untuk Peramalan Data Penjualan Bulanan. 2010.

[6] Song, Q. dan Chissom, B. S. "Forecasting enrollments with fuzzy time series-Part I”. Fuzzy Sets and Systems, 54: 1-9. 1993.

[7] Song, Q. dan Chissom, B. S. "Forecasting enrollments with fuzzy time series-Part II”. Fuzzy Sets and Systems, 62: 1-8. 1994.
[8] Wangren Qiu, Xiaodong Liu dan Hailin Li. A generalized method for forecasting based on fuzzy time series. Expert System with Applications. 38, 1044610453. 2011

[9] Xihao, S., Li Yimin. Average-based fuzzy time series models for forecasting shanghai compound index. World Journal of Modelling and Simulation Vol.4 pp. 104-111. 2008. HTTP://www.lbma.org.uk (Akses setiap hari untuk mendapatkan data harga emas).

[10] Huarng, K. \& Yu H. K. A type 2 fuzzy time series model for stock index forecasting. Physical A, vol. 353, pp. 445462. 2005. 